\title{
2 \\ Shifting democracy: Electoral changes in Fiji
}

\author{
Steven Ratuva
}

Electoral systems play a pivotal role in shaping voter political behaviour and choices, the national political culture and institutional political governance processes of a country. Scholars of electoral engineering have often differed on the most appropriate electoral system because different systems have different philosophical assumptions about democracy; and also they tend to create different outcomes based on the type of voting system, how constituency boundaries are designed and how the electoral system is manipulated by political parties and candidates to their advantage. In ethnically divided societies like Fiji, the focus has been increasingly on identifying an electoral system that promotes moderation, provides proportionality and representativeness and enhances inter-group harmony and long-term stability (Fraenkel \& Grofman 2006; Horowitz 1997; Lijphart 1994; Reilly 2001). However, some electoral systems are configured specifically to suit the local circumstances or the interests of local elites or particular social groups at a particular point in time. Also, different electoral systems are based on certain assumptions about what democracy means, what it ought to be, how it should work and what the behavioural outcomes should be (Scholdan 2000). 
While some theories of constitutional engineering such as the rational choice institutional approach (Norris 2004) have been influential, they tend to be too focused on individual behavioural dispositions and choices and how these interface with institutions; they often ignore the broader ethno-political and cultural dynamics which help shape group choices. In Fiji, constitutional engineering has been influenced by a number of factors. The first past the post (FPTP)based electoral system under the 1970 Constitution, together with the communal allocation of seats, was inspired by the desire to create ethnic representativeness and balance and inter-ethnic harmony in a potentially volatile ethno-political situation. The shift in the balance of power after the 1987 elections created the conditions for military intervention. Following the coup, the 1970 Constitution was abrogated and a new one was promulgated in 1990 which retained the FPTP system and which was based on the assumption that stability could be achieved only through Taukei (indigenous Fijian) hegemony. This constitution was deemed inoperable in a multiethnic situation and it was amended, leading to the 1997 Constitution, which proposed an alternative voting (AV) system in the hope of creating moderation and stability (Lal 1998). This expectation was shattered by the 2000 coup. Today Fiji's new open list proportional representation (OLPR) electoral system, provided for in the 2013 Constitution, has been justified on the ground that it will steer the country away from an ethnic-based contestation for power and political mobilisation promoted by past FPTP and AV models. While this is true at the institutional level, whether it actually changes people's thinking and political behaviour in a way that negates communal consciousness is a big and challenging question.

This chapter examines some of the broad patterns of electoral change in Fiji, focusing fundamentally on the differences between the FPTP, $\mathrm{AV}$ and OLPR - their characteristics and their implications for shaping Fiji's ethno-political landscape.

\section{The first past the post system}

The FPTP system is based on a winner takes all approach: it is easy to administer and count and the results from highest to lowest are ordered through a simple process of ranking. The winner is the one who scores 
a simple majority of one vote above the second highest. Most countries in the Pacific, such as Tonga, Samoa, Solomon Islands and Cook Islands, use the FPTP system. In some cases, the constituencies are so small that the difference between the winner and runner-up is as small as one to three votes. In these cases, recounts often take place and these can be expensive. After the 27 November 2014 elections in Tonga, for example, the former Ha'apai No. 12 people's representative Mo'ale o'ale Finau, who won 532 votes but lost his seat by a margin of three votes, applied for a recount and was required to pay a recount fee of TOP\$1,000 (Fonua 2014).

The FPTP voting system was used in Fiji's first election under universal suffrage in 1966 when the Fijian Association, the forerunner to the Alliance Party, won 22 seats. In addition to these, five other independents and Great Council of Chiefs nominees were aligned to the Alliance Party and in total it was able to muster 27 seats in the Legislative Council. The Indo-Fijian National Congress, which later became the National Federation Party (NFP), won nine seats (25 per cent) in the 36-seat legislature (Lal 2008). With three times more votes than the NFP, this was the largest victory the Alliance Party was to ever win. Prior to 1966, Taukei representatives were nominated while Indo-Fijian and European representatives were directly elected by voters. This patronising system was based on the assumption that Taukei interest was best served by chiefs through the Great Council of Chiefs as well as other colonially patronised institutions such as the Native Land Trust Board, Fijian Affairs Board, provincial councils (Bose ni yasana), district councils (Bose ni tikina) and village councils (Bose vakoro).

At the time of independence in 1970, Fiji's dilemma was how to accommodate the distinctive communal interests of competing ethnic groups in an overarching national rubric. It was a classic case of accommodating the often competing and potentially volatile aspirations of ethno-nationalism and civic nationalism (Stavenhagen 1996). The solution, after horse-trading between the leaders of the two major ethnic groups, was a consociationalist arrangement, encapsulated in the 1970 Constitution, whereby the Taukei and Indo-Fijians were to be allocated the same number of seats. To appease the Taukei, who feared political domination by Indo-Fijians and loss of land and political rights, there was agreement that the Senate would provide greater Taukei representation. 
The first election under the 1970 Constitution, in 1972, saw shifts in the results compared to the 1966 elections. Based on the FPTP system, the gap between the Alliance Party, which won 33 seats ( 63 per cent), and the NFP, which won 19 seats (37 per cent), began to close. The allocation of seats under this constitution was largely communal in nature. Of the 52 seats, 22 were reserved for the Taukei, 22 for IndoFijians and eight for other minorities, usually categorised as 'General Electors'. The 22 seats for each of the two major ethnic groups were further divided into 12 communal (elected by members of the same community) and 10 national roll seats, to be elected cross-ethnically. For the general electors the division was three communal and five national roll seats (Fiji Government 1970). The ethnic division at this early stage was very clear, with the Alliance Party winning all the Taukei communal seats with the support of 82 per cent of all Taukei votes, and all general communal seats. The NFP won all Indo-Fijian communal seats, securing 73 per cent of all the Indo-Fijian votes. The voter turnout for the communal seats overall was 85.2 per cent.

Based as it was on the FPTP system, elections under the 1970 Constitution should have been relatively straightforward, but they were complicated by the communal allocation of seats in different categories, as mentioned above. Each voter actually had four votesone in his or her own local communal constituency and one each for the 'national' constituencies for all three communal groups (i.e. Taukei, Indo-Fijian and General). This required four separate ballot papers. For instance, a Taukei voter would vote for a candidate in his or her local communal constituency (in which all the candidates and voters were Taukei), then the same voter would also vote three more timesone for each of the 'national' (cross-communal) seats for Taukei, Indo-Fijians and General Electors.

Because all four votes were counted, the tally of total votes as well as of party votes appeared to be inflated: the total number of votes was 689,673, although the population of Fiji was barely 400,000 in 1972. Another feature of the voting system was the disparity between the proportion of the votes and the number of seats. The Alliance Party polled 57.5 per cent of the votes but won 33 or 63.4 per cent of the seats; the NFP with 33.9 per cent of the votes won 19 or 36.5 per cent of the seats; and the Fijian Independent Party, which won 0.2 per cent of the votes, and independents, who won 6.4 per cent of the votes, both failed to win any seats (Nohlen, Grotz \& Hartmann 2001). 
The second election under the 1970 Constitution was held in March 1977, when the NFP sent shockwaves through the Taukei political establishment after they won 26 seats to the Alliance's 24 seats, despite the Alliance gaining 46 per cent of the votes as opposed to NFP's 45.2 per cent, an unfortunate disparity created by the FPTP system. Under the current OLPR system, the Alliance could have won the elections with about 24 seats, but the Alliance Party actually lost nine seats and the NFP gained an extra seven seats, while the Fijian Nationalist Party (FNP) and an independent candidate won a seat each. The more than 39,000 votes collected by FNP contributed to the Alliance defeat. There were altogether 47,690 informal votes, a high number indeed (Fiji Elections Office 1977).

The NFP was not able to form a government following the elections due to an internal leadership struggle and other factors and the governorgeneral, Ratu Sir George Cakobau, invited Ratu Sir Kamisese Mara, the former prime minister and leader of the defeated Alliance, to take over as caretaker prime minister in a 'palace coup' of sorts until the next elections in September of the same year.

The September 1977 elections saw the Alliance's fortunes shift in their favour. The Alliance won 36 seats, a gain of 12, while the NFP, which by then was divided between the 'flower' and 'dove' factions, lost 11 seats, ending up with 15 (12 for the flower faction and three for the dove faction). The FNP votes declined by more than half as Taukei voters realised that votes for the FNP (which lost almost half of its support) would weaken the Alliance, thus risking the possibility of Taukei losing political power as in the March elections. The number of informal votes increased to 51,713 .

Again, as in previous elections, the disparity in the percentage of the votes and number of seats was quite marked. The Alliance Party polled 52.2 per cent of the votes but won a massive 69 per cent of the seats; the NFP (flower) won 23.7 per cent of the votes and won 23.07 per cent of the seats, indeed a rare coincidence of proportionality under the FPTP system; the NFP (dove) won 20.6 per cent of the votes but won only 5.7 per cent of the seats; and perhaps the biggest loser was the FNP, which won 18,854 votes but did not win any seat, while the independent candidate won a seat with only 6,228 votes. 
The disparity between votes cast and seats won was not really obvious during the 1982 elections, when the Alliance Party, with 51.8 per cent of the votes, won 53 per cent of the seats, while the NFP won 42 per cent of the seats with 41.2 per cent of the votes. This election saw the entry of the western Viti Levu-based Western United Front (WUF), which won two seats. The number of informal votes reduced to 19,605 , a low total compared to the previous elections (Fiji Elections Office 1982).

The last and most significant election under the 1970 Constitution's FPTP system was the April 1987 elections, which led directly to the May and September 1987 coups, following which Fiji's politics was drastically transformed through a serious of coerced regime changes (Ratuva 2011). In 1987, the Alliance Party lost power, winning only 24 seats, although they won 49.5 per cent of the total votes. With only 47.1 per cent of the votes, the NFP-Fiji Labour Party (FLP) coalition won 28 seats, or 54 per cent. One key factor contributing to the coalition victory was the new energy and promise provided by the newly formed FLP. Also the shift of Taukei votes to the WUF and FNP, although the latter once again failed to win a seat, drew votes away from the Alliance Party. The shift in the balance of power away from the Taukei establishment created the conditions for instability in a highly charged ethno-political climate. Again, as in the previous elections, the exaggerated total of over 1 million votes for a population of about half a million was reflective of the type of multiple votes required under Fiji's communal FPTP electoral system.

The FPTP system under the 1970 Constitution had a number of distinguishable factors. The fact that voters had to vote four times complicated the process and inflated the total number of voters by a factor of four. This meant that voters did not necessarily have to vote for the same party on all four ballot papers: one for the voter's communal seat, one for the voter's national seat and two for the national seats of the other two ethnic categories. This system provided a chance for both trans-ethnic and communal voting within the broader rubric of ethnic classification. The complexity of the system led to a large number of informal votes. Another feature was that the seats won were disproportionate to the votes because of the large differences in the size and number of voters in different constituencies. 
While the electoral system under the 1970 Constitution was seen as a panacea for Fiji's divergent communal interests because it prescribed a seemingly balanced voting equation (especially the provision for an equal number of seats for Taukei and Indo-Fijians), in some ways that prescription reinforced communalism and entrenched what has been described as 'communal democracy' (Ratuva 2005). These elections did not really serve the purpose of a power-balancing exercise, which the seat allocation formula was assumed to do, but became an arena for both inter- and intra-ethnic contestation of choice and power. When there was a shift in political gravity away from the Alliance Party and, effectively, the Taukei establishment, Fijian democracy, which up until then was underpinned by the notion of paramountcy of Fijian interest, began to unravel in unrestrained ways.

The May 1987 coup, a month after the elections, led to a fundamental transformation of Fiji's political environment, including the declaration of Fiji as a republic and the promulgation of the 1990 Constitution which promoted Taukei political ascendency (Lawson 1991; Norton 1990; Sutherland 1992). There was a dramatic transformation from the discourse of balance to the discourse of communal hegemony, spawned by the waves of Taukei ethno-nationalism that have swept Fiji since 1987. The 1990 Constitution prescribed a FPTP electoral system with 70 parliamentary seats, 37 of which were reserved for Taukei, 27 for Indo-Fijians, one for Rotumans and five for other ethnic minorities (Fiji Government 1990, p. 49). There were no national seats as in the 1970 Constitution. Another significant development was the demise of the Alliance Party and the emergence of the Soqosoqo ni Vakavulewa ni Taukei (SVT) as the dominant Taukei party.

Predictably, the first general elections under the 1990 Constitution, held in 1992, was won by the SVT with 43.6 per cent of the votes and 30 seats, or 43 per cent. This was an unusual coincidence of vote-seat proportionality. Indo-Fijian votes were largely shared between the NFP with 16.1 per cent (14 seats) the FLP with 16.1 per cent (13 seats). This even split in votes can be interpreted as a result of the equal level of appeal of the two political parties amongst Indo-Fijian voters at this time, but that was to change dramatically in the next elections. After a long drought the FNP made a comeback under a new name (Fijian Nationalist United Front), winning three seats. The WUF also made a comeback with two seats and the General Voters' Party (GVP), 
because it was the only party representing the General Electors, won all five general communal seats (7.14 per cent) but with only 1.4 per cent of the total votes (Fiji Elections Office 1992).

The balance of power in the new parliament was very precarious. With only 30 seats and a slim majority, the SVT struggled to hold on to power and it came as no surprise that a snap election took place two years later in 1994 after the government failed to pass its budget through parliament. The SVT came back strongly in the elections, winning two extra seats with 40.9 per cent of the votes. The NFP also increased its number of seats by six to 20 (17.8 per cent of the votes) at the direct expense of the FLP, which lost six seats and ended up with seven (14.6 per cent of the votes). The newly formed Fijian Association Party (FAP), a direct rival to the SVT, won five seats ( 9.9 per cent of the votes) while the FNP won 4.1 per cent of the votes and lost its three seats. The number of informal votes was the lowest ever up to that point (Fiji Elections Office 1994). The 1994 elections were the last under the FPTP system before a review of the 1990 Constitution. This review saw major revisions, leading to the 1997 Constitution that introduced the alternative voting (AV) system.

The political dynamics in Fiji had started to swing in a way that the framers of the 1990 Constitution did not envisage. The ethnic distribution of seats to guarantee Taukei hegemony was premised on the assumption that Taukei political interest and aspirations were homogenous and solidarity of the vanua (Taukei culture and social structure) was primordially indivisible. This mythical view failed to appreciate and acknowledge the contesting tribal, regional and ideological discourses within the Taukei community, some of which are rooted in pre-European times. The split within the SVT and the formation of the FAP testified to this. The SVT, with only 30 seats, was faced by opposition from both the Taukei and Indo-Fijian political parties.

The voting system under the 1990 Constitution was relatively simple. Every voter voted for only one candidate in the single-member communal constituency. This was a significant contrast to the mixed communal and cross-voting system of the 1970 Constitution, which required four ballot papers for each voter. Because of its simplicity, the informal vote was quite low. Despite this, the undesirability of this electoral system was its ethnically skewed nature, which provided the 
Taukei disproportionate political power and simultaneously reduced other ethnic groups into marginalised political subalterns. The system further fragmented Fiji's multicultural society and overseas migration by Indo-Fijians continued unabated as they attempted to escape from the communally restrictive political climate.

The FPTP system under the 1970 and 1990 Constitutions was framed around the reservation of ethnic seats in multiple singlemember constituencies. While the 1970 Constitution prescribed a mixture of communal and national rolls to accommodate a mixture of intra- and inter-ethnic votes, the FPTP system under the 1990 Constitution was totally communal, without any trans-ethnic votes. Nevertheless, both variants encouraged ethnic mobilisation and the creation of communally based political cleavages, which contributed to tension and instability. This was because the communally based FPTP system created the conditions for ethnic-based competition for political power on the basis of a winner takes all contest. Ethnic-based political parties became the vehicle for promoting and facilitating the ethnic struggle for political ascendency on the basis of zero-sum gamesmanship. The mixture of the winner takes all principle under FPTP and ethnically exclusive political mobilisation overshadowed the potential for middle-ground compromises. This nurtured the development of a demarcated and antagonistic political culture, which, over time, laced with economic disparity, ethnic competition over state control and deliberate ethnic mobilisation, spawned largescale ethno-political schism.

A negative feature of the FPTP system was the disparity in the proportionality of votes in relation to the number of seats. We have seen this occur in all the elections under FPTP since universal suffrage was introduced in 1966. The number of seats won by political parties was often disproportionate to the votes they had won. In addition, the figures show that the winners of the elections in 1966, 1970, 1987, 1992 and 1994 did not achieve the 50 per cent threshold to be able to claim majority support. This raises the technical and ethical question of the democratic value of votes and whether attaining victory by winning less than 50 per cent of the votes was sufficient to make a victory legitimate. This was a major dilemma that the AV system attempted to address when it was introduced under the 1997 Constitution. 


\section{The alternative voting system}

As Fiji moved away from the shadow of the 1987 coup and its associated Constitution of 1990, internal and external pressure for a more ethnically accommodating constitution increased. After a constitutional review process by the constitutional commission, which carried out local and international consultation, parliament unanimously passed the 1997 Constitution. The AV system used in Fiji under the 1997 Constitution was considerably more complex than the FPTP system previously used. A major rationale behind the use of the $\mathrm{AV}$ system was a belief in its capacity to ameliorate tension by fostering cooperation and moderation (Horowitz 1997; Reeves, Vakatora \& Lal 1996; Reilly 2001). This was because the system allowed for a consociationalist process based on exchange of preferences between political parties. Theoretically the AV system was supposed to provide middle-ground consensus as well as remove extremism and promote opportunities for minority parties to win seats. However, like any other electoral system, the AV system was subject to manipulation by politicians and this, to some extent, had some influence on electoral outcomes.

Of the 71 seats provided for under the 1997 Constitution, 25 were to be open seats in which voters could vote for any candidate from any ethnic group, while 46 seats were reserved for specific communities. In these communal seats, 23 seats were reserved for the Taukei, 19 for Indo-Fijians, one for Rotumans and three for other minorities. The boundaries for 17 of the constituencies were based on the administrative provincial boundaries prescribed under the Fijian Affairs Act; each of the larger provinces of Ba, Tailevu and Cakaudrove were divided into two constituencies, and each of the other provinces became a single constituency. The remaining six constituencies were comprised predominantly of urban and peri-urban areas containing roughly equal numbers (Fiji Government 1997). In terms of the value of votes (determined by seat-voter ratio), the rural provincial constituencies, which were demographically smaller in size, had more advantage than the urban and peri-urban constituencies.

The ballot paper was divided into two parts: the 'above the line' vote required voters to tick the party of their choice and the 'below the line' vote required voters to list the candidates in order of preference 
from 1 to 5 . If no candidate achieved 50 per cent plus one vote of the valid votes cast in a constituency, the votes of the lowest-polling candidate were redistributed among the other candidates according to the preferences listed on the ballot paper. This process was repeated until one candidate had at least 50 per cent plus one vote of the total valid votes cast.

The system of preferential exchange between parties tended to nullify the power of voters to determine the outcome of their votes. In fact it was tantamount to parties 'fixing' the election results, as parties traded preferences to maximise benefits for themselves while conspiring against those they detested. For instance, during the 1999 elections, the first under the AV system, the Veitokani ni Lewenivanua Vakarisito (VLV) and the Party of National Unity (PANU), two moderate Taukei parties, gave high preferences to the Indo-Fijian-dominated FLP as a tactical move to undermine the NFP and Soqosoqo Duavata ni Lewenivanua (SDL), who had formed a close alliance. In the 2001 elections, NFP transferred its votes to SDL, thus enabling it to win, although the NFP failed to win a single seat (Fiji Elections Office 1999).

During the 1999 elections, many voters found the AV system complex and confusing, and the informal vote was as high as 10 per cent. In addition, there was a massive disparity in the proportion of seats in relation to the votes, similar to elections under the FPTP system. For instance, with only 32.2 per cent of the total votes after distribution of preferences, the FLP won 52.1 per cent of the seats. On the other hand, the NFP, with 14.6 per cent of the votes, failed to win a seat, while the Fijian Association Party (FAP), with only 10.1 per cent of the votes, won 10 seats. The UGP, with a mere 1.4 per cent of the votes, won two seats. This disparity in vote value raised fundamental questions about the viability of the AV system as an electoral mechanism for democracy, especially in an ethnically divided society.

The AV system did indeed promote minority parties and interparty cooperation, much more than the FPTP system had. However, the problem was that the inter- and intra-communal formal engagements were still 'floating' on deeply embedded ethnic cleavages and consciousness, whipped up by ethnic entrepreneurs who had personal and political motives. This, together with a host of other factors, including Chaudhry's governance style, built up the momentum towards the 2000 coup. 
The attempt by the NFP and SVT, two major ethnic parties, to forge an alliance failed because the leaders, Jai Ram Reddy (NFP) and Sitiveni Rabuka (SVT), could not secure the backing of their respective communities. To the Indo-Fijian voters, Reddy was committing sacrilege by allying himself with the man who staged the 1987 coup against Indo-Fijian political interests. To his Taukei supporters, Rabuka was seen as selling out Taukei interests by crossing the sacred line that kept the Indo-Fijians and Taukei apart. The attempt to move towards a middle ground position was a tectonic shift that reflected the new spirit of the 1997 Constitution and the AV system and the appeal for moderation. However, this came into direct collision with the highly ethnicised political culture nurtured under the communally oriented FPTP. Voters showed their dissatisfaction through the ballot: the SVT lost a total of 24 seats, winning only eight, and there was a mass exodus of Indo-Fijian voters from the NFP to the FLP. The latter won a massive 37 seats while the NFP lost 20. The FLP was now seen as the party representing Indo-Fijian interests, an image propped up by its use of racial fearmongering among Indo-Fijian voters. Its leader, Mahendra Chaudhry, became the first Indo-Fijian prime minister.

The FLP forged a coalition with the FAP and VLV and held power for a year before being overthrown in the coup of May 2000. While the $\mathrm{AV}$ system cannot be blamed for the increasing ethnic polarisation, it could not really transform a political culture, which had long thrived on ethno-political polarity in a significant way. The process of party cooperation was not sufficient to heal the ethno-political schism.

The demise of the SVT led to the emergence of the SDL, an even more strongly ethno-nationalist party. During the 2001 elections, the SDL, under the leadership of Laisenia Qarase, who was appointed by the military as interim prime minister after the 2000 coup, won 32 seats with only 26 per cent of the votes, while the FLP, with 34.8 per cent of the votes, won only 27 seats. The Conservative Alliance, a party formed by supporters of George Speight, the ethno-nationalist coup leader, won six seats and subsequently formed a coalition with the SDL (Fiji Elections Office 2002).

The 2006 elections continued to show the dominance of the SDL and FLP as major ethnic political groupings for Taukei and Indo-Fijians respectively. With 44.59 per cent of the votes, the SDL won 36 seats and with 39.18 per cent of the votes, the FLP won 31 seats (Fiji Elections 
Office 2006). The results showed an increasingly polarised society, dashing expectations that $\mathrm{AV}$ was going to create a middle ground consensus.

The proliferation of political parties under the AV system stemmed from misplaced optimism about its capacity to facilitate minority party interests. The real dynamic behind how the AV system worked was how parties strategically shared their preferences both to benefit themselves and to undermine the chances of parties perceived as arch rivals. By and large, this led to major ethnic parties such as the SDL and the FLP making deals that promoted their interests while undermining intra-ethnic competitors. As we have seen, inter-ethnic deals usually ended up promoting the dominance of a major ethnic party.

Following the military coup in December 2006, which saw the overthrow of the SDL government, a new political order was created after a fundamental political transformation (Ratuva 2011). Among the changes was the creation of a new constitution prescribing an open list proportional representation system (OLPR), which was used for the first time in the 17 September 2014 elections.

\section{The open list proportional representation system and the 2014 elections}

The underlying principle of the proportional representation (PR) system is that the proportion of seats won by a party or independent candidate corresponds with the proportion of votes gained. There are basically two types of PR systems: the closed system, in which the political parties provide a list of candidates; and the open system, where the candidates are ranked according to how many votes they win. Fiji uses the 'open' PR system. The ballot paper consists of numbers allocated to the candidates and the voter has to put a tick, a cross or a circle in the box beside the number of the candidate he or she supports. Other variants of the PR system include the mixed member proportional (MMP) system used in New Zealand and the single transferable vote (STV) used in Ireland. About 94 countries in the world use different variants of the PR system. The party list is the most popular, with about 85 countries using it. 
The introduction of the open list proportional representation (OLPR) system and the single national constituency system in Fiji is meant to promote trans-ethnic voting, multiethnic political party membership and national unity. As we have seen earlier, communally based constituencies under the FPTP and AV systems promoted ethnic contestation for political power, which contributed to tensions. The single national constituency ensures that politicians are not locked into localised loyalty but rather have a broader national outlook. The open listing is also meant to democratise the elections through the direct choice of the voters rather than allowing the political parties to determine the winning candidates through a closed list system. The number of parliamentary seats has been reduced from 71 to 50 as a way of creating a leaner and less expensive parliament.

The ballot paper is in the form of a grid containing the number allotted to each candidate, picked at random, starting from number 135. This avoided single digit numbers such as 1 , which would give some candidates unfair advantage. The design of the ballot paper caused considerable controversy because political parties felt that simply allocating numbers to represent candidates was too simplistic and confusing for voters. An alternative suggestion was a ballot paper with party symbols. The use of the number grid represents an extreme version of design options. The other extreme is to list the names and symbols of all 247 candidates by using a 'tablecloth' ballot paper containing details such as names of candidates and party symbols. This option is not practical but there are other variations in between the two extremes that could show party symbols and even names. These could have been explored.

The vote-counting system uses the $\mathrm{D}^{\prime}$ Hondt method first suggested by Victor D'Hondt, a Belgian mathematician, in 1878. It involves dividing the total number of votes a party receives by a series of denominators from 1 to 50. Thus, the total vote is divided by 1 then the remainder is divided by 2 then the remainder is divided by 3 and then by 4 and so forth, until 50 (because of the 50 seats). The seats are then divided amongst political parties that polled more than the threshold of 5 per cent of the total votes; the allocation of seats is based on the proportion of votes they gain. For instance, a party that polls 50 per cent of the votes gets 50 per cent of the seats and one which polls 10 per cent of the votes receives 10 per cent of the seats. From the party's total seat allocation, the individual seats are then allocated 
according to their ranking within the party, based on the individual votes they receive. For instance, with 60 per cent of the votes, FijiFirst (FF) was allocated 60 per cent of the seats, which totalled 32 seats. The FijiFirst candidates were then allocated seats on the basis of the 32 highest-polling candidates.

\section{Results of the 2014 elections}

As Table 1 shows, the elections delivered a decisive victory for FijiFirst with 59.17 per cent of the votes and 32 seats, followed by the Social Democratic Liberal Party (SODELPA), a renamed version of the SDL. The revived NFP won three seats, while none of the other four parties and two independent candidates reached the 5 per cent threshold and thus they failed to win any seats. In a way, the OLPR system had opened up the space for multiethnic competition, with all the parties claiming to be multiethnic although the degree to which they were in terms of membership or support varied considerably.

Table 1: Election results by political party

\begin{tabular}{|l|r|r|r|}
\hline Political party & Total no. of votes & Percentage & No. of seats \\
\hline FijiFirst & 293,714 & 59.17 & 32 \\
\hline SODELPA & 139,857 & 28.18 & 15 \\
\hline NFP & 27,066 & 5.15 & 3 \\
\hline PDP & 15,864 & 3.2 & 0 \\
\hline FLP & 11,670 & 2.35 & 0 \\
\hline One Fiji & 5,839 & 1.18 & 0 \\
\hline FUFP & 1,072 & 0.22 & 0 \\
\hline Roshika Deo & 1,055 & 0.21 & 0 \\
\hline Umesh Chand & 227 & 0.05 & 0 \\
\hline Total & 496,364 & 100 & 50 \\
\hline
\end{tabular}

Source: Fiji Elections Office (2014).

Note: The figures in this table have been rounded up and do not exactly match the totals supplied.

FijiFirst (FF) turned out to be the biggest beneficiary of the new system by appealing nationally across ethnic groups. The party leader himself, Frank Bainimarama, won a massive 202,459, 41 per cent of all the votes cast, which was 12.6 per cent higher than the total SODELPA 
votes, 70 per cent of all FF votes and four times more than the votes won by Ro Temumu Kepa, the leader of the SODELPA. Bainimarama's votes created a 'coat-tail effect': his votes enabled members of his party with very low votes to win seats (Fiji Elections Office 2014).

The estimate for the ethnic and party distribution of the votes in Table 2 shows the extent to which FF extended its electoral success across all ethnic groups, winning 50 per cent of Taukei votes, 71 per cent of Indo-Fijian votes and 80 per cent of minority votes. In comparison, SODELPA initially strived to present itself as multiethnic but failed to attract sufficient non-Taukei candidates, winning only 0.4 per cent of Indo-Fijian votes and 1.5 per cent of minority votes. Although its campaign focused on attracting Taukei votes, they managed only 46 per cent of all Taukei votes.

Table 2: Estimates of ethnic votes and percentage

\begin{tabular}{|l|r|r|r|r|r|r|r|}
\hline Party & & Taukei & \multicolumn{2}{|r|}{ Indo-Fijian } & \multicolumn{2}{|r|}{ Minority } & Total \\
\hline FF & 148,909 & $50 \%$ & 120,979 & $71 \%$ & 23,826 & $8 \%$ & 293,714 \\
\hline SODELPA & 137,523 & $46 \%$ & 751 & $0.4 \%$ & 432 & $1.45 \%$ & 139,857 \\
\hline Others & 11,386 & $4 \%$ & 47,034 & $28 \%$ & 5,533 & $18.57 \%$ & 62,793 \\
\hline Total & 297,818 & $100 \%$ & 168,764 & $100 \%$ & 29,782 & $100 \%$ & 496,364 \\
\hline
\end{tabular}

Source: Estimated from Fiji Elections Office figures for 2014.

Note: The figures in this table have been rounded up and do not exactly match the totals supplied.

Because FF had an undisputed dominance over Indo-Fijian and minority votes, the real battle to determine the winner was between FF and SODELPA as they battled over the Taukei votes, which made up 60 per cent of the total voters.

\section{Taukei versus Taukei contest}

One of the central trends in the 2014 Fiji general elections was the contestation for political dominance by indigenous Fijian (Taukei) elites representing the two major political parties: the FF and the SODELPA. The differences between FF and SODELPA were deeply rooted in their different conceptualisations of Taukei history, cosmology, culture and the future direction of Taukei social transformation. SODELPA's ideological position supported a protectionist doctrine harking back 
to the colonial and post-colonial period, while FF was committed to the fundamental transformation of neo-colonial institutions, norms and ideologies.

As already stated, FF scored a decisive victory with almost 59.17 per cent of the total votes and about 50 per cent of the Taukei votes, compared to SODELPA's 28.18 per cent and 46 per cent respectively. The almost 50/50 split in the Taukei votes was indicative of major changes in social dynamics within the Taukei community as well as in the relationship with other communities. This will continue to shape the future trajectory of Fijian politics in significant ways.

The OLPR system opened the way for a three-tier, all-out contest between first, political parties; second, individual candidates of different political parties; and third, candidates of the same party. Taukei votes consisted of 297,818 (60 per cent) of a total of 496,364 votes. As noted above, this was the main battleground for FF and SODELPA. Because SODELPA was a predominantly Taukei party, with an exclusively ethno-nationalist ideology, it was statistically and politically handicapped from the beginning - it had to win 247,188 or 83 per cent of the Taukei votes to be able to reach the $25(+1)$ seat threshold to form government in the 50-seat parliament.

The 139,857 votes for SODELPA equated to about 46.9 per cent of Taukei votes. The non-Taukei votes for SODELPA may have come largely from the three Indo-Fijian candidates, whose votes totalled 751, and Mick Beddoes, a member of the minority part-European group, who collected 865 votes. If we assume that about half of Beddoes's votes came from Taukeis then the approximate number of minority groups who voted for SODELPA would be about 432. Thus the total number of non-Taukei votes for SODELPA would be about 1,183 or 0.85 per cent of the total SODELPA votes and 0.2 per cent of the overall national votes. Thus we can conclude that of the total SODELPA votes, about 137,523 or 99.1 per cent, were Taukei. This represented 46 per cent of the total Taukei votes.

Predictably, the last two candidates in the SODELPA list were IndoFijians. In the beginning, SODELPA was optimistic about attracting other ethnic groups but abandoned the idea of a multiracial party after failing to attract sufficient non-Taukeis to stand as candidates. If it hopes to have any chance of winning a future election, SODELPA basically has two choices. The first is to increase its share of Taukei 
votes by 83 per cent and more, a virtually impossible feat. Second, it should reconfigure its ideological and political strategy in a more trans-ethnic direction and compete head on against the FF on the same multiracial platform.

In contrast to SODELPA, FF clearly has a trans-ethnic appeal and therefore had a lower level of difficulty in winning, because all it needed was 50 per cent Taukei votes, 50 per cent Indo-Fijian votes and 50 per cent votes from other minorities to reach the 25 seats threshold. Anything on top of that was a bonus. This meant SODELPA had to work harder by 33 per cent than FF to reach its 83 per cent threshold. With 46 per cent of the Taukei votes going to SODELPA, the share for FF and minority parties was 54 per cent. Assuming that the minority parties' share of Taukei votes was 4 per cent, the other 50 per cent would have voted for FF. This clear division in Taukei votes reflected the shifting nature of Taukei interests, expectations and political choices in a fast-changing social, economic and political environment. This is a significant lesson for electoral strategising in the next elections for political parties who hope to win Taukei votes.

With 148,909 (50 per cent) of Taukei votes (or 29.9 per cent of the total votes) secured, all that FF had to do to ensure total victory was to top up with Indo-Fijian and minority votes. In the end, FF secured 293,714 or 59.17 per cent of the total votes, about twice as many as SODELPA, with 139,857 or 28.18 per cent of the total votes. In addition to the Taukei votes, the Indo-Fijian and minority voters who voted for FF totalled around 144,805 or 29.1 per cent of the total FF votes. Based on the assumption that Indo-Fijians made up 34 per cent of the total votes, the total number of Indo-Fijian votes was 168,764, while the total number of minority votes (again assuming that they made up 6 per cent of the total votes) was 29,782 . If we assume that 80 per cent $(23,826)$ of the voters from minorities voted for FF, then about 120,979 (71 per cent) of the Indo-Fijians would have done the same.

The margin of error for these calculations is about 2 to 3 per cent but, by and large, given the absence of any official figures on ethnic categorisation, this estimation, based on_the figures available, gives us a good idea of the dynamics of shifting voting patterns. The fact that there was an almost 50/50 split in the Taukei votes between SODELPA and FF means that one cannot talk strictly about a 'Taukei Party'; and in the same way that one can no longer confidently talk about an 'Indo-Fijian Party'. 


\section{Election strategies}

SODELPA's strategy in carving up the single national constituency into 50 sub-constituencies as the focus of its campaign for the 50 individual candidates was quite innovative and commendable because it won the party most of their seats. Winning SODELPA candidates did well in their allocated local areas by taking advantage of kinship and other sociocultural links within the local community. The only SODELPA candidate who collected substantive votes across the subconstituency boundaries was party leader Ro Teimumu, with a massive 49,485 votes, light years ahead of Niko Nawaikula, who came second with 7,348 votes. However, while this strategy worked well in rural areas it was less successful in semi-urban and urban areas. These were FF territories.

The FF approach was in direct contrast to that of SODELPA. FF used the 'rock star' phenomenon very strategically by cleverly using the VFR principles (visibility, familiarity and relevance), which underpinned the voter-politician relationship in the OLPR system. The focus was on maximising the VFR of the already well-known party leader Bainimarama to draw votes for the party. This also worked well in the context of the number grid system used in the ballot paper, where one just needed to remember the number 279. Also, FF's presidential campaign style, its use of 'cargo cult' politics (provision of development projects) and a last minute pro-poor manifesto, amongst other strategies, helped to consolidate its dominance. These tactics achieved phenomenal results, especially for the FF leader, who also won votes for another 49 members of the party who collectively won only 30 per cent of the party votes. It is often assumed that one of the advantages of the PR system is to ensure greater parity in the votes between parties, but the lopsidedness of the votes in favour of FF destroyed this assumption.

FF had an advantage over other parties in terms of incumbency and access to state resources as well as through its control over the media and freedom of association during the pre-election period. It also effectively marketed its development projects to voters, sometimes with veiled threats of what might happen if FF did not win the elections. Eight years of unrivalled hegemony entrenched their visibility, familiarity and relevance in voter consciousness. 
It is reasonable to assume that if an election had taken place in 2009, FF would have struggled to win because at that time the country was still going through a turbulent period and the Bainimarama regime had very little to market to voters.

Political contestation between FF and SODELPA centred on the very different ideological positions adopted by each. SODELPA's vision of land, the Great Council of Chiefs, identity and the Christian state placed it at the protectionist, ethno-nationalistic and conservative end of the continuum (SODELPA 2014), while FF was more towards the reformist, secularist, modernist and multiethnic end (FijiFirst 2014). What they shared in common were tactics involving psychological coercion in the form of private and public fearmongering. Rumours, conspiracy theories and hate stories were circulated widely through blog sites, social networks and other means, both modern and traditional, of communication. This created much tension and negative energy, which unfortunately did not really wither away after the elections but instead continued unabated into the 2015 parliamentary debates.

The stark ideological distinction between the two parties provided voters with a clear choice. Indo-Fijians and minority groups found the FF position more trans-ethnically embracing and supportive of their long-term security in Fiji compared to the ethnically exclusivist SODELPA position. For the Taukei, the choice was between SODELPA's conservative cultural preservation approach or FF's cultural transformation and socioeconomic modernisation strategy. The patterns of Taukei support for both parties were apparent. SODELPA had massive support in the rural polling stations of Lau, Kadavu and Lomaiviti as well as in Cakaudrove and Bua, while FF performed well in Viti Levu, especially in Nadroga, Nadi, Ba, Serua, Ra, Naitasiri and Tailevu. For instance, Cuvu, Nadroga's 'capital', was overwhelmingly FF, despite the close kinship links between Cuvu and the SODELPA leader. In Tailevu, home of the FF leader, the tussle was quite even but SODELPA dominated in Rewa, home of SODELPA's leader (Fiji Elections Office 2014).

Data from polling stations in urban areas such as Lami, Kinoya, Nausori, Nasinu, Raiwaqa, Nabua, University of the South Pacific, Fiji National University and Suva Civic Centre, amongst others, showed that FF had unsurpassed support (Fiji Elections Office 2014) in these places. Thus it appears that support for SODELPA was strong among 
the more traditional and conservative members of the rural Taukei community, while support for FF was dominant amongst the more urban and also those who had direct benefit from the government's development projects. But development did not always work as a payoff for party loyalty. For instance, although a large number of development projects in the form of roads and mining had taken place in the Bua province, FF still performed very badly in many Bua polling stations. In a Kadavu polling station, despite the provision of solar electricity to the villages concerned, only two people voted for FF out of a total of 77 voters.

The OLPR system will likely be around for some time yet because provisions for amending the Constitution are very restrictive; for instance, three-quarters of parliamentary votes are required in addition to support by three-quarters of voters in a national referendum. The new system promised hope of representation for minority parties and independents but there were disappointments, as only three parties won seats. While it ensured parity between the number of parliamentary seats a party gained and the number of votes it had received, it still created discrepancies in the actual ranking of individual candidates. For instance, there were winning candidates in FF who collected fewer votes than losing candidates in SODELPA. Bainimarama's coat-tail appeal may have distorted the actual total support for $\mathrm{FF}$, as winning party members actually benefitted from the massive support for Bainimarama. The FF tactic of deliberately and actively promoting their party leader as a political rock star attracted popular votes and worked to their advantage. Perhaps the burning question for FF is what happens when Bainimarama is gone, perhaps in two or three elections' time. This is when competition between political parties will be stiffer and the results more unpredictable.

\section{Conclusion}

Fiji has come a long way in its electoral journey from the FPTP used in the first universal suffrage in 1966 and post-independence elections under the 1970 and 1990 Constitutions to the AV system under the 1997 Constitution and eventually the OLPR system under the 2013 Constitution. The FPTP system was used in the context of communally divided constituencies, as reflected in the 1970 and 1990 Constitutions, which helped nurture and reproduce the creation of communal 
political cleavages and ethnic contestation for political power. Ethnic politics became a significant driver for defining sociocultural identity and social change. One's ethnic identity and political rights became closely linked in an almost symbiotic manner.

Attempts to move away from this communal political culture led to the introduction of the AV system under the 1997 Constitution. Theoretically, the AV system was meant to promote inter-ethnic engagement and moderation but given the simmering ethno-political dynamics in Fiji, the experiences in the 1999, 2001 and 2006 elections showed that sharing of preferences by parties was based not on their desire to move towards moderation but on the desire to leverage the system to maximise self-interest. The results still showed an ethnically polarised pattern of votes.

The introduction of the OLPR system was part of the post-2006 political revolution to transform the sociopolitical landscape by eradicating ethnic mobilisation and consciousness. This has not been fully achieved because of the difficulty in de-ethnicising people's identity and choices. Nevertheless, the rise of FF has shifted political discourse to the centre, where expressions of political choices by different ethnic groups have converged. The results of the 2014 elections appear to show that Fiji's political culture has shifted away from ethnic polarity towards moderation. The next elections in 2018 will indicate whether this shift is substantive or merely temporary.

\section{References}

Fiji Elections Office 1977, Election Results, Fiji Elections Office, Suva.

Fiji Elections Office 1982, Election Results, Fiji Elections Office, Suva.

Fiji Elections Office 1992, Election Results, Fiji Elections Office, Suva.

Fiji Elections Office 1994, Election Results, Fiji Elections Office, Suva.

Fiji Elections Office 1999, Election Results, Fiji Elections Office, Suva.

Fiji Elections Office 2002, Election Results, Fiji Elections Office, Suva.

Fiji Elections Office 2006, Election Results, Fiji Elections Office, Suva. 
Fiji Elections Office 2014, 'Final results for the 2014 general election'. Viewed 5 December 2014 at www.electionsfiji.gov.fj/2014-electionresults/.

Fiji Government 1970, Constitution of the Republic of Fiji Islands, Government Printing Press, Suva.

Fiji Government 1990, Constitution of the Republic of Fiji Islands, Government Printing Press, Suva.

Fiji Government 1997, Constitution of the Republic of Fiji Islands, Government Printing Press, Suva.

Fiji Government 2013, Constitution of the Republic of Fiji, Government Printing Press, Suva.

FijiFirst 2014, Manifesto. Viewed 26 November 2014 at fijifirst.com/ our-manifesto/\#toggle-id-1.

Fonua, P 2014, 'Ballot recount for Ha'apai 12 candidate', Matangi Tonga, 5 December. Viewed 10 December 2014 at matangitonga. to/2014/12/06/ballot-recount-ha-apai-12-candidate.

Fraenkel, J and Grofman, B 2006, 'Does the alternative vote foster moderation in ethnically divided societies? The case of Fiji', Comparative Political Studies, vol. 39, no. 5, pp. 623-51.

Horowitz, DL 1997, 'Encouraging electoral accommodation in divided societies', in BV Lal and P Larmour (eds), Electoral systems in divided societies: The Fiji constitutional review, The Australian National University, Canberra, pp. 21-37.

Lal, B 1998, Another way: The politics of constitutional reform in postcoup Fiji, Asia Pacific Press, Canberra.

Lal, B 2008, A time bomb lies buried: Fiji's road to independence, 1960-1970, ANU E Press, Canberra.

Lawson, S 1991, The failure of democratic politics in Fiji, Oxford University Press, Oxford.

Lijphart, A 1994, Electoral systems and party systems, Oxford University Press, Oxford.

Nohlen, D, Grotz, F and Hartmann, 2001, Elections in Asia: A data handbook, Volume II, Oxford University Press, Oxford. 
Norris, P 2004, Electoral engineering: Voting rules and voting behaviour, University of Cambridge Press, Cambridge.

Norton, B 1990, Race and politics in Fiji, University of Queensland Press, St Lucia.

Ratuva, S 2005, 'Political and Ethnic Identity in a Post-colonial Communal Democracy: The Case of Fiji', in A Allahar (ed.), Ethnicity, class and nationalism: Caribbean and extra-Caribbean dimensions, Lexington Books, Oxford.

Ratuva, S 2011, 'The Fiji Military Coups: Reactive and Transformative Tendencies', Journal of Asian Political Science, vol. 19, no. 1, pp. 96-120.

Ratuva, S 2013, Politics of preferential development: Trans-global study of affirmative action and ethnic conflict in Fiji, Malaysia and South Africa, ANU E Press, Canberra.

Reeves, P, Vakatora, TR and Lal, BV 1996, The Fiji Islands: Towards a united future, Report of the Fiji Constitutional Review Commission, Parliament of Fiji, Parliamentary Paper No. 34, Fiji Government Printer, Suva.

Reilly, B 2001, Democracy in divided societies: Electoral engineering for conflict management, Cambridge University Press, New York.

Scholdan, S 2000, 'Democratisation and electoral engineering in postethnic conflict societies,' Javnost - The Public, vol.7, no. 1, pp. 25-40.

SODELPA 2014, Reclaiming Fiji, SODELPA, Suva.

Stavenhagen, R 1996, Ethnic conflict and the nation state, Palgrave Macmillan, London.

Sutherland, W 1992, Beyond the Politics of Race: An Alternative History of Fiji to 1992, Research School of Pacific Studies, The Australian National University, Canberra. 
This text is taken from The People Have Spoken: The 2014 Elections in Fiji, edited by Steven Ratuva and Stephanie Lawson, published 2016 by ANU Press, The Australian National University, Canberra, Australia. 